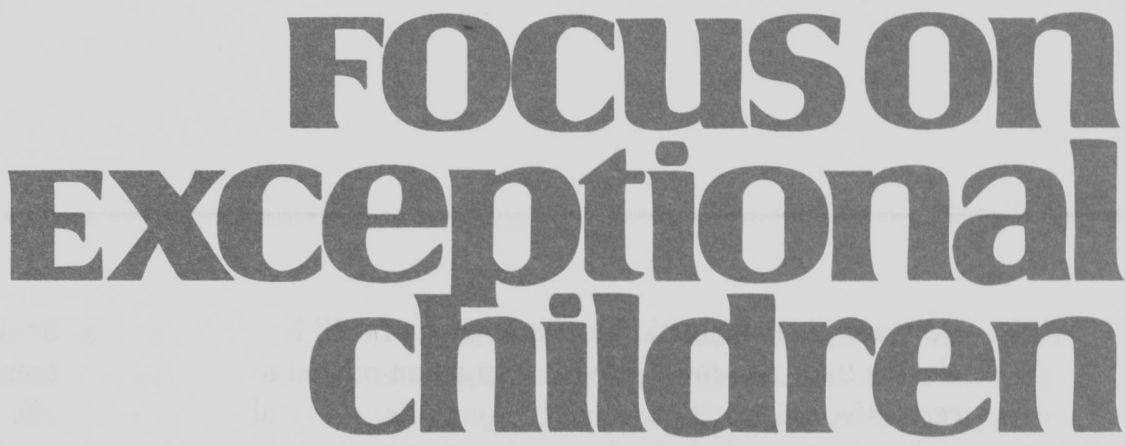

\title{
Secondary Inclusion Programs for Students with Mild Disabilities
}

\author{
Cassandra McCrory Cole and James McLeskey
}

The movement toward more inclusive school programs has resulted in increasing numbers of students with mild disabilities (learning disabilities, mild mental retardation, and behavior disorders) who are educated in general education classroom settings (Espin \& Foegen, 1996; Guterman, 1995; Scanlon, Deshler, \& Schumaker, 1996; Smith, Polloway, Patton, \& Dowdy, 1995). Although the effectiveness of inclusive school programs has remained controversial (Fuchs \& Fuchs, 1994; McLeskey \& Waldron, 1995; Zigmond et al., 1995), the movement toward these programs seems to be continuing unabated.

Until recently, much of the emphasis in the professional literature regarding inclusion focused on programs in elementary schools. Many of the efficacy studies that have been used to support inclusion have been conducted in elementary schools, and the model programs that have been described have primarily been elementary programs (Affleck, Madge, Adams, \& Lowenbraun, 1988; Banerji \& Dailey, 1995; Bear \& Proctor, 1990; Zigmond, et al., 1995). Indeed, it seems likely that many more inclusion programs have been developed in elementary schools, and secondary schools have been much slower in moving toward developing and implementing these programs.

\section{BARRIERS TO DEVELOPMENT OF SECONDARY INCLUSIVE SCHOOL PROGRAMS}

Many possible reasons exist as to why inclusive programs have developed more slowly at the secondary level when compared to elementary schools. These barriers to program development likely have contributed to the perceived resistance toward inclusive programs on the part of teachers and administrators in secondary schools. These barriers include the following:

1. At the secondary level, teachers emphasize complex curricular material; at the elementary level they teach basic academic and social skills.

2. There is a larger gap between the skill level of students and classroom demands at the secondary level. Students with disabilities at the secondary level lack the basic academic skills, as well as learning skills/strategies necessary for success (Rieth \& Polsgrove, 1994; Schumaker \& Deshler, 1988; Zigmond, 1990).

3 . The secondary level has a much broader range of curricular content than the elementary level does. Not only are secondary schools responsible for curricular con-

Cassandra McCrory Cole is associated with Southside Elementary School, Columbus, Indiana. James McLeskey is affiliated with the Department of Curriculum and Instruction, Indiana University. 
tent such as mathematics across a range of skill levels, but they also must provide instruction related to careers/vocations, functional living skills, survival skills, transition from high school to a variety of settings, and so forth.

4. Secondary classrooms tend to be teacher-centered, in which instruction is most often didactic, directed to large groups, and infrequently differentiated for varying student needs. This results in teachers spending small amounts of time with large numbers of students each day, and limited contact with any single student (Schumaker \& Deshler, 1988).

5. Teachers at the secondary level are trained as content specialists. Some cannot or are not inclined to make adaptations for students with disabilities who do not master the curricular content. In addition, teachers may be frustrated by the limited, slow progress that students with disabilities make in their classes (Smith, Polloway, Patton, \& Dowdy, 1995).

\section{FOCuson
Exceptional children}

ISSN 0015-511X FOCUS ON EXCEPTIONAL CHILDREN (USPS 203-360) is published monthly except June, July, and August as a service to teachers, special educators, curriculum specialists, administrators, and those concerned with the special education of exceptional children. This publication is annotated and indexed by the ERIC Clearinghouse on Handicapped and Gifted Children for publication in the monthly Current Index to Journals in Education (CIJE) and the quarterly index, Exceptional Children Education Resources (ECER). The full text of Focus on Exceptional Children is also available in the electronic versions of the Education Index. It is also available in microfilm from Xerox University Microfilms, Ann Arbor, MI. Subscription rates: Individual, \$30 per year; institutions, $\$ 40$ per year. Copyright (C) 1997, Love Publishing Company. All rights reserved. Reproduction in whole or part without written permission is prohibited. Printed in the United States of America. Periodicals postage is paid at Denver, Colorado. POSTMASTER: Send address changes to:

$$
\begin{gathered}
\text { Love Publishing Company } \\
\text { Executive and Editorial Office } \\
\text { P.O. Box } 22353 \\
\text { Denver, Colorado } 80222 \\
\text { Telephone (303) } 757-2579
\end{gathered}
$$

Edward L. Meyen

University of Kansas

Richard J. Whelan

University of Kansas Medical Center
Stanley F. Love

Publisher
Glenn A. Vergason Georgia State University
Thomas Love Associate Editor
6. Students are going through a complex, sometimes frustrating personal transition through adolescence, which affects their emotional, social, sexual, physical, and academic development (Mercer \& Mercer, 1993). Even under the best of circumstances, academics tend not to be the primary interest of many of these students.

7. The pressure from outside agencies is greater in secondary schools. Accountability on the secondary school for providing students with certain skills and knowledge is demanded from businesses, state governments, colleges and universities, and the general public.

8. Secondary teachers tend to have significant autonomy as they develop their course offerings. This makes coordinating knowledge and skills across courses difficult (Schumaker \& Deshler, 1988).

Given these barriers, it is not surprising that inclusive school programs have been slow to develop at the secondary level. This dearth of program alternatives has led to some controversy regarding just what inclusive programs at this level should entail. Most seem to agree that the programs should differ from elementary programs (Schumaker \& Deshler, 1988) and that students should not necessarily spend $100 \%$ of the school day in general education classroom settings; some students, for example, should spend time in community or work settings or settings in which intensive support services may be provided (Kauffman, Lloyd, Baker, \& Riedel, 1995; York \& Reynolds, 1996).

In addition, considering the high rate at which students with disabilities are unsuccessful (or fail) in general education classrooms (Blackorby \& Wagner, 1996; Rieth \& Polsgrove, 1994; Schumaker \& Deshler, 1988), it seems apparent that if students with mild disabilities are to be educated successfully in general education classrooms in secondary schools, these classrooms must be transformed so the organization, curriculum, and instruction provided is designed to meet the needs of a diverse group of students (Deshler \& Schumaker, 1988). In spite of the general consensus regarding these issues, there is much less agreement regarding the emphasis that should be placed on various curricular content areas, the location in which this material should be presented, and who should present this information.

\section{SECONDARY CURRICULAR CONTENT NEEDS FOR STUDENTS WITH MILD DISABILITIES}

Decisions regarding which curricular content areas to emphasize are especially difficult because secondary teachers of 
students with disabilities have an acute shortage of time to address the many educational needs of secondary-level students (Deshler, Schumaker, Lenz, \& Ellis, 1984). Curricular areas for which secondary-level teachers of students with disabilities may have partial or full responsibility include the following:

1. Basic academic skills. These skills involve instruction in basic skills such as reading, writing, and mathematics that are deficient for students with disabilities. Even among students with learning disabilities, basic reading, writing, and math skills are lacking when they enter adolescence (Espin \& Foegen, 1996; Schumaker \& Deshler, 1988; Zigmond, 1990). For example, Schumaker, Deshler, Alley, and Warner (1983) found that as these students enter the 10th grade, they tend to have basic skills that plateaued at the fourth or fifth grade level. Instruction in basic academic skills often is provided outside of the general education classroom, in a separate special education classroom by a teacher of students with disabilities (Zigmond, 1990).

2. Tutorial programs (Deshler, Schumaker, Lenz, \& Ellis, 1984). This approach emphasizes tutorial support of students in general education content classes (e.g., English, mathematics, social studies, science). Tutorial support typically is provided in separate resource classrooms by the teacher of students with disabilities.

3. Compensatory programs and support in general education classes (Deshler, Schumaker, Lenz, \& Ellis, 1984). This approach is designed to facilitate the adaptation of general education classrooms so students with disabilities can succeed in these settings. Typically the general education and special education teachers work together to adapt classroom organization, curriculum, and instruction to meet the needs of all students in the setting. This approach may be used with content or vocational classes.

4. Learning strategies programs (Deshler, Schumaker, Lenz, \& Ellis, 1984; Ellis, 1993). This approach is not designed to teach specific content but, rather, focuses on teaching students skills related to "how to learn." Much evidence indicates that students with disabilities lack these skills, which are critical for learning, solving problems, and completing tasks independently in general education classrooms. These skills may be taught in a separate setting by a teacher of students with disabilities or, as Ellis (1993) has proposed, as part of an Integrated Strategy Model that combines classroom content and general strategy in- struction. In the latter model, the general and special education teachers teach these skills collaboratively.

5. Instruction in survival skills (Zigmond, 1990) and life skills (Polloway, Patton, Epstein, \& Smith, 1993). Zigmond (1990) has proposed that secondary teachers of students with LD should teach these students skills they need to survive in school, including behavior control, teacher-pleasing behaviors, and study skills/testtaking strategies. Polloway et al. (1993) have proposed that students with disabilities at the secondary level would benefit from a life skills curriculum, which would teach them skills to support successful adjustment after they complete school. A teacher of students with disabilities teaches survival skills and life skills in a separate, special education classroom.

6. Vocational training. Vocational training is provided for students with disabilities as they prepare to make the transition from school to a work setting. This instruction frequently is provided by specialists in vocational education, assisted by teachers of students with disabilities in adapting for the needs of students with disabilities. Vocational instruction also is provided in work settings through work-study and supported employment programs.

7. Transition planning. Often included as part of vocational training, transition planning also may include a life skills curriculum, in which students are taught functional skills they need on the job and in other community settings (Polloway, Patton, Epstein, \& Smith, 1993). The life skills curriculum is taught most often by a teacher of students with disabilities in a separate setting.

As the above list illustrates, secondary-level teachers of students with disabilities face a broad range of demands on their time to address these curricular areas. Clearly, priorities must be developed regarding which curricular areas should be emphasized, and teachers of students with disabilities must organize and use their time to maximize their efficiency and effectiveness. We readily admit that there are no easy answers regarding what inclusive school programs in secondary schools should entail, how they should be organized, what should be taught, where instruction should occur, and so forth. Indeed, from our perspective, each secondary program should be tailored to the specific needs of a given setting, thus precluding the possibility of a "one-size fits all" model program.

With these caveats in mind, the following section describes an inclusive school program currently in operation in a high school in a small midwestern city. This high school began de- 
veloping an inclusive program eight years ago. The program subsequently achieved a high level of success and has been recognized as a model program for delivering inclusive school services (CEC, 1995).

\section{DEVELOPING A SECONDARY-LEVEL INCLUSIVE SCHOOL PROGRAM}

Eleanor Roosevelt High School is located in a midwestern city with a population of approximately 50,000. A large state university is located nearby. A rich blend of small urban, suburban, and rural communities feeds into Roosevelt High School. The diversity of the community is illustrated by the fact that a major university is located in the same county that closed the last two-room school house in the state in 1965.

Eleanor Roosevelt High School has a student population of 1,350 students, $93 \%$ of whom are caucasian, $2 \%$ AfricanAmerican, $4.5 \%$ Asian, and a small number of international students from more than 35 countries. Of the students at Roosevelt, $34 \%$ live in rural settings, $30 \%$ in suburban settings, and $36 \%$ in urban settings. Ten percent of the students at Roosevelt qualify for free or reduced lunches. Roosevelt employs approximately 80 full- and part-time professionals.

Implementation of the inclusive school program at Roosevelt High School began in the 1990-91 school year. Discussion regarding changes in the program, however, began two years prior to implementation, when members of the special education department began to assess and critically analyze special education services and student success. Roosevelt had a highly successful program for students with substantial needs; these students were being served in an ageappropriate building, attended general education classes with their peers, were provided vocational skills through a work study/supported employment program, and often left high school with paid employment.

Several faculty members in special education began to question the services provided for students with mild disabilities and believed this program was much less successful than the program for students with substantial needs. Even though students with mild disabilities most often left school with a diploma, they were not always able to secure paid employment and often had few skills that would enable them to become contributing members of the community. Overall, academic expectations for these students were extremely low. Based on these observations, several faculty members in special education thought they should begin to look at doing something different.

At about the same time, members of the special education department were becoming cognizant of the movement to- ward inclusion and the literature supporting the integration of students with disabilities into the general education classroom (Will, 1986). Discussions took place initially at staff meetings and in informal conversations. From these discussions, a team of teachers was convened to begin to plan seriously for teachers in general and special education to collaborate in teaching core content areas. This group drafted a written proposal and presented it to Roosevelt's Curriculum Council in October 1989. The rationale for changes that were proposed rested on five major points.

1. The English department was moving toward a more heterogeneous grouping of students. This provided an opportunity to include students with disabilities in these classes and to involve teachers of students with disabilities in the discussion, planning, and implementation of this new instructional arrangement.

2. Similar types of curricula were being used in the general math class and the special education math class. Both of these math classes were addressing basic arithmetic, and teachers from both courses believed the courses should be restructured totally to make them more applicable to the students' needs.

3. Both teachers of students with disabilities who would be involved initially in teaming with general educators had dual licensing in special education and the content area in which they would teach. This was important practically speaking because it satisfied the state's licensing requirements and eliminated the need for a waiver.

4. Collaborative efforts would result in growth experiences for students and teachers alike.

5. Teachers thought the wider diversity in student characteristics at Roosevelt would require all teachers to learn from each other and to share their expertise.

The initial proposal identified two sections designated for collaborative teaching: a ninth grade general math class and an 11th grade English class. The staff in special education was paired with general education faculty in each class section. All four individuals were voluntary participants. This core group then identified the following objectives for students:

1. To integrate students from general and special education.

2. To provide contact between same-age peers from general and special education.

3. To expose students to a greater variety of teaching strategies. 
4. To develop in students appropriate skills in English and math.

5. To provide and share peer reinforcement.

6 . To be exposed to a greater number of peer role models.

In addition, the following objectives were developed for faculty involved in the inclusive program:

1. To deliver services to a broader range of students.

2. To integrate faculty in general and special education.

3. To promote the use of effective educational practices for all students.

4. To introduce collaborative teaching techniques.

5. To give the teaching staff the opportunity to share expertise.

6. To encourage the use of a wide variety of teaching strategies.

7. To develop guidelines and directions for faculty members who may develop similar programs in the future.

8. To encourage teachers to view themselves as decision makers with respect to developing, presenting, and assessing collaborative teaching techniques.

The program at Roosevelt High School is beginning its seventh year of implementation. Self-contained special education classes have been reduced from 21 sections in the first year of the program to three at present. Collaborative teaching partnerships now extend to all core curricular areas, and teacher participation continues to be voluntary.

\section{Decisions Regarding Curriculum}

In developing an inclusive school program at Roosevelt High School, clear decisions were made regarding which areas of the curriculum would be emphasized and how teachers of students with disabilities would spend their time. These decisions were difficult, they involved compromise, and they are being adjusted continually to ensure a good fit with the student population. The following provides a brief description regarding these decisions and a rationale for making them.

The staff at Roosevelt High School decided not to offer separate-class special education programs in basic academic skill areas (reading and mathematics), for four basic reasons. First, teachers believed that students with mild disabilities had already had eight (or more) years of instruction in these basic skill areas, and this instruction most often had resulted in continuing poor performance in basic skills, as well as much frustration on the part of students when they addressed these topics in separate, special education classrooms. The staff also was aware that previous pullout, basic skills instruction at Roosevelt had not been effective. As Zigmond
(1990) so aptly stated, students with learning disabilities tend to enter high school three to five years behind actual grade placement and "unfortunately ... do not seem to recoup these basic skill deficiencies during their years of attending secondary school resource programs ... and, in fact, the gap between achievement scores and grade expectancy level actually seems to widen as students with learning disabilities progress through high school" (p. 5).

Second, the faculty at Roosevelt realized that when students were in basic skills classes, they were missing important opportunities to be exposed to a rich curriculum, cooperative learning experiences, and classroom discussions that would provide beneficial learning experiences for them (see Oakes (1985) for a discussion of curriculum inequality).

Third, the faculty made the decision to discontinue separate classes in basic skill instruction because they believed that the time of teachers of students with disabilities could be better spent in other activities (which will be described subsequently) that would provide more benefits for students with disabilities.

Fourth, evidence indicated that literacy skills learned in isolation (i.e., in separate reading classes) tended not to transfer to other academic or vocational content areas (Mikulecky, Albers, \& Peers, 1994; Mikulecky \& Lloyd, 1993). This finding, as well as experiences of the faculty at Roosevelt that supported this contention, led the faculty to decide that literacy and numeracy skills could be taught best within the context of content-area classes (i.e., English, science, vocational classes, and so forth) rather than teaching reading and mathematics as separate subject areas. Thus, the faculty did not "give up" on teaching literacy and numeracy skills to students with disabilities. For example, students would learn new vocabulary in an auto mechanics or a social studies class, read books in English classes, learn math skills in a practical mathematics class, and participate in a variety of other activities to increase their literacy and numeracy skills.

Faculty members who participated in general education partnerships realized the importance of tutorial services for students with disabilities. These services helped students organize their work, complete homework, study for tests, learn study skills related to content-area subjects, and so forth. The faculty also recognized that many students who were not labeled as having disabilities needed these services. To address the need for this type of support, a schoolwide program was developed to provide tutoring to all students who needed these services. The program involved administrators, teachers, paraprofessionals, peer tutors, and volunteers.

Teachers believed that learning strategies, survival skills, life skills, and transition planning were taught best within 
the context of ongoing classes that provided a natural setting for teaching and applying these skills. Indeed, some of the general education classes were transformed to offer some aspects of these curricular areas to a wide range of typical students as well as students with disabilities. Thus, separate special education classes addressing these topics were discontinued.

Vocational opportunities for students with mild disabilities continued to be offered through an area vocational school located on the campus of Roosevelt High School. The teachers of students with disabilities worked collaboratively with vocational staff and school counselors to develop programs to meet student needs. One major change in the vocational education program resulted from the success of the this program for students with substantial needs. These students were gaining important employment opportunities through a community-based supported employment/work study program. The faculty recognized that students with mild disabilities would benefit substantially from similar experiences. Thus, the community-based work study program was expanded to include students with mild disabilities, who were provided onthe-job training and community access skills during the school day.

\section{PARTNERSHIPS AS THE FOUNDATION OF SECONDARY INCLUSIVE PROGRAMS}

The foundation for the program in special education at Roosevelt High School was built on partnerships between general education teachers and teachers of students with disabilities, as they addressed the curricular area called "compensatory programs and support in general education classrooms." As the partnerships evolved, teachers changed their perspectives significantly regarding what this type of program should entail. Prior to development of the inclusive school program, "compensatory and support" programs were viewed primarily as support services provided by the teacher of students with disabilities to allow students with mild disabilities to succeed in the general education classroom. These programs did not question the curriculum, instruction, or classroom organization of the general education classroom. Thus, "the problem" was perceived to reside within the student, and the role of the teacher of students with disabilities was viewed as making sure the student could fit into the general education classroom.

As partnerships developed, teachers concluded quickly that this perspective had to change. They found that though students with mild disabilities indeed lacked some of the skills manifested by typical students, these deficits could be addressed best by changing the general education classroom and assisting students with disabilities within these settings to gain the skills necessary to succeed. Thus, as part of these partnerships, teachers worked to transform the general education classroom to better meet the needs of all students. The partnerships often resulted in significant changes in the curriculum of the general education classroom, methods of delivering instruction, and classroom organization. Classes also often became more student-centered and less teacher- or content-centered.

Through these partnerships, teachers work collaboratively to transform the general education classroom (organization, curriculum, and instruction) to better meet the needs of all students in the classroom, including students with disabilities. In the following section we describe how these partnerships develop, followed by an example.

\section{Examining Current Practice}

As collaborative partnerships begin to form in high schools, participants first must reflect on and understand the assumptions and specific training that teachers from special and general education bring to the classroom setting. In the initial stages of an inclusion program, as partnerships are beginning, teachers of students with disabilities typically enter into a minefield of uncertainties and begin to question the knowledge base and traditions that undergird their professional training. A critical examination and reappraisal of the practice of special education is important as it affords teachers an opportunity to address and challenge the basic assumptions and traditions in which their day-to-day decision making is grounded. It allows them to discuss options for students and teachers, which ultimately changes the way they view their profession.

To achieve this goal, special educators must ask themselves some difficult questions:

- What difference does it make for me and for my students if I enter into this partnership and no longer practice in a separate setting/system?

- What expertise do I have that is of value to the general education classroom?

- What about the current practice of special education is good and should be kept?

- What about the current practice of special education is not good and should be discarded?

- What role should I have in a general education classroom?

A critical examination and reappraisal of the practice of general educators entails asking questions similar to those above: 
- What difference does it make for me and for my students if I enter into this partnership, and no longer practice in a separate setting/system?

- What expertise do I have that is of value to students with disabilities?

- What about my current instructional practices and curriculum is good and should be kept?

- What about my current instructional practices and curriculum is not good and should be discarded?

- What role should I have in a partnership with a teacher of students with disabilities?

By looking at their profession and practice in new and different ways, these teachers are able to consider their actions, intentions, and effects thoughtfully. They begin to plan for change based on what they know about themselves, their school, and their students.

\section{Examining Contrasting Perspectives on Teaching and Learning}

In addition to examining their own beliefs, teachers who are beginning partnerships must share this information and also examine how their beliefs and values differ from those of their partner. For example, in most instances the greatest difference between secondary-level general education teachers and teachers of students with disabilities relates to their perspectives on students and instruction.

As Cuban (1984) noted, general education teachers at the secondary level tend to be subject-focused and teacher-centered, whereas teachers of students with disabilities tend to be more student-centered. The experience and training of general education teachers has focused on ways to help students learn a specific subject: how to understand algebra, how to learn to write well, how to communicate, how to use a calculator. In contrast, the training of teachers of students with disabilities often centers on methods for ensuring student success by adapting instruction, altering curriculum, and so forth.

These different perspectives lead to differing practices in the classroom that must be addressed before a partnership can be successful. In a subject- or teacher-centered classroom, the teacher tends to talk more than students (much lecture is used to convey information efficiently), the classroom is organized to support lectures (with rows of desks facing the front of the room), and most instruction occurs with large groups. In contrast, in classes with student-centered instruction, students talk more and receive less lecture, the teacher uses more small-group and individual instruction is used, varied instructional materials and methods are more varied to address stu- dent needs, and the classroom is arranged to reflect these differences (to facilitate the use of cooperative groups).

Until teachers address and share these different perspectives on instruction and learning, developing successful partnerships is difficult, if not impossible. This process helps teachers to understand their partners' strengths, as well as their own strengths that they bring to the teaching partnership.

\section{Determining Teacher Strengths}

Teachers entering into a partnership must discuss their perception of their teaching strengths, as well as their shortcomings. This discussion will help the partners gain a new perspective on and respect for the strengths of their partner, as well as a better understanding of where their own strengths lie. When these discussions take place, the general education teacher's firm grasp of the course content and strong skills related to organizing this material and conveying it to large groups of students may become apparent. In contrast, teachers of students with disabilities often have less knowledge of the curriculum and more skills related to determining critical elements of the curriculum and adapting instruction to convey this information to small groups of students.

These complementary skills often form the foundation upon which partnerships are built, as both teachers feel good about the strengths they bring to the partnership and feel confident that their combined expertise will improve instruction for all students in the classroom. This is reflected in the following comment by a teacher of students with disabilities at Roosevelt. ${ }^{1}$

\begin{abstract}
You walk in and you see where a student is, emotionally, socially, academically, behaviorally. I mean, you start there. That's the only place I feel you can be effective. I think I take what the general education teacher sees in a general scope and make sure that it fits the individual students, tailoring the language, even the format of the worksheet, even the quantity of the work required. I will tailor or trim it down to the student who I just know is going to be mechanically slow on this. They can do it, but they are not going to do the quantity that somebody else will do.
\end{abstract}

\section{Risk Taking and Partnerships}

In developing partnerships, the partners also have to clearly understand the risk involved for both participants. The partners often discover that the perception of the risk involved in moving into a collaborative teaching partnership varies greatly. Upon reflection, this difference is understandable.

\footnotetext{
${ }^{1}$ All quotes are taken from Cole (1995).
} 
Most frequently, general educators who become involved in a collaborative teaching effort do not believe they are taking a major risk. These teachers seem to understand that entering into a partnership might mean a change in how they normally would conduct one or two of their classes, but they do not feel at great risk personally or professionally. They still have a classroom, they still have the same number of (or a few additional) students they would have had if they had taught alone, and they feel confident about their expertise in the curricular area.

In contrast, teachers of students with disabilities entering into teaching partnerships often feel at great risk professionally and personally. These teachers often are required to change their entire professional identity as they enter into partnerships with general educators. Teachers of students with disabilities perceive that they must give up more than their partner does, including the loss of much of their identity as specialists, loss of their students and their classrooms, and loss of much of their autonomy as a teacher. In addition, these teachers often fear they lack the expertise to function effectively in a general education classroom, as they have little experience in this setting, are unfamiliar with the curriculum of the classroom, and are unaccustomed to teaching large groups of students.

Thus, as a partnership begins, a teacher of students with disabilities is attempting to define her role, learn the curricular content, and deal with 30 or more students in a classroom. In addition, these teachers may be in the process of developing partnerships with two, three, or more teachers. Under these circumstances, no wonder they often fear that entering into a teaching partnership will lower their professional status and that they may end up serving as a paraprofessional in the general education classroom.

\section{Developing Trust and Respect}

Trust and respect are necessary in co-teaching and collaboration. This takes several forms: trust and respect for teaching partners, for other colleagues involved in the program, and for administrators. Sharing responsibility and accountability takes time and depends in part on development of the partnership. Even though respect for a teaching partner may be present from the beginning, the trust of their partners as individuals takes some time.

Hartgraves (1993) proposes two dimensions to trust-predictability and common goals - and suggests that trust manifests itself as confidence instilled in persons or process. By responding to personal and professional concerns and by not bailing out at the first moment of stress, teachers begin to trust their partners. As this trust grows, the participants are better able to express their individual views, concerns, and ideas; they are able to be more vocal about the things that are important to them.

Trusting each other to make key decisions after years of being the sole decision maker in the classroom is a major change for teachers. As a math teacher at Roosevelt commented:

I think the other thing is the decision-making process. You are so used to doing it yourself that if you are going to get something done the way you want it done, you do it yourself. And even though you know the person you are with is very competent and can do it all, it is easier to do it yourself than to ask them to do it. Now I feel comfortable saying, "Hey, here is what I would like to do. What do you think?" and my partner will say "Okay, I'll make the test out and make sure we cover this," and there is no conversation about what should be on it, because I feel like the marriage has really settled in and we have become one.

\section{Voluntary Participation}

Along with trust and respect, involvement in co-teaching should be voluntary, not forced. Participants often liken it to a marriage; the interpersonal relationships necessary for coteaching cannot be mandated. Giving educators this choice and allowing them to seek information and ask critical questions about the choice offers more ownership in the effort. Likewise, providing teachers with a choice gives them a sense that they have the support of their administration.

\section{Administrative Support}

Administrators play a major role in developing positive teaching partnerships. Teachers need to know that their administration will provide the necessary support. This may include having administrators cover teachers' classrooms so they can have time to meet to reflect on the program. It may mean that administrators facilitate staff development needs and ensure that schedules for students and staff are appropriate. Administrators need to provide the emotional support necessary when times got tough, and provide a "safety net" for teachers by communicating that they will not have the "limb chopped off" if they step out and try new and different things.

\section{Communication}

Communication is critical to the collaborative teaching effort. The necessary communication requires being able to speak as well as listen, sharing information and developing shared meaning, and being willing to provide and accept interpersonal feedback. Teachers have to "place the issues on the table," to talk about problems, both big and small. This communication has to be ongoing and may take place in a 
formal, structured fashion (as in a workshop or staff meeting) and in an informal way (in the hall, at lunch, in the parking lot, or at a social gathering.)

Communication might be both professional and personal in nature, addressing student and classroom needs as well as the personal needs of a teaching partner. Reflection and action must occur with respect to the students in the class as well as the relationship of the individual teachers as they work to form a teaching partnership. Rather than relying on standard responses to instructional problems, teachers should generate new thoughts and ideas to guide their actions in the classroom.

Problems are attendant to this type of interdependency. Working closely with another professional presents a new set of human relations issues. The conflicts that arise have to be dealt with both personally and professionally. Control issues, a lack of privacy, and sharing ownership of a class are concerns that have not been faced in a loosely coupled system wherein teachers have taught alone. Now they have to learn to communicate in new and different ways, to make time for each other, and to become more flexible. Talking about their practice in a critical, reflective way is something that teachers must learn over time.

\section{Achieving Parity}

Although some time is required for teachers in some partnerships to reach parity, there must be a clear notion that when presenting themselves to students, the teachers are coteachers, not the special education teacher and the math teacher. As a math teacher said:

\begin{abstract}
We are co-teachers from the word go, from the ground up. He's not determining curriculum, I'm not determining curriculum. It's two heads are better than one. We tell students, "We are your teachers." We put the names up on the board, they stay up there all year long, and we go right into what the class is about and what they are going to experience this year, and we don't say another word about the roles we might play. We don't even explain it. I can't recall anybody asking, "Why are there two teachers in here?" They just kind of sit in here, and there are two teachers!
\end{abstract}

A teacher of students with disabilities further commented on this same partnership:

From minute one we had to present ourselves as coteachers. The minute the students get wind of "Oh, I see, you're just kind of a helper", as teachers we all know what is going to happen to your perception by those students. If you are seen as only helping certain students and not others, you'll be limited in your effect with all the students in that classroom. There are very concrete ways to present ourselves as co-teachers. It is always "we," "our policy, our restroom policy is, our feeling about textbooks is, today this is what we are going to do," as opposed to presenting only one teacher's viewpoint. We have found that has done wonders to start students right from the beginning as seeing us as co-teachers.

The classroom is a place to start sharing. The room that once belonged to one teacher now is home for two. Each teacher should have ownership of the room, whether it be sharing a desk or having two desks in the room. This not only makes a difference to the partner, but the students will benefit as well and not be confused with "who's the boss?" The students need to see the team in harmony to produce good results, and two teachers sharing a common goal of students' success is a good example for the student.

The parity issue must reach beyond sharing teaching responsibilities. Teachers, especially special education teachers, believe the little things are just as important to share. This includes physical space issues such as a desk, a chair, a place to put their things, and a file cabinet. Trivial as it may seem, issues such as this become important as the teams work toward being equal partners. As a teacher of students with disabilities stated:

\begin{abstract}
The fact that I have a desk is important. It is a table that I have in both of the classrooms that I go into, but that is my area, so I can say to a student who is supposed to turn in a book: "put your papers ... your journals on my desk," and they know that. They see my partner and me as co-equals within that classroom. It becomes just one more tangible way of setting up the fact that we have equal responsibility and that kids can go to either one for help or answers to questions.
\end{abstract}

Developing trust, being committed to open communication, and clearly defining roles bring the individual teachers in each partnership to the co-equal relationship they often had envisioned from the beginning. Special educators may spend the beginning stages of a partnership defining their roles and establishing their contribution to co-teaching. Partnerships mature at different rates, but eventually each partnership should be able to develop a strong professional relationship, both within and outside of the classroom, and be able to share responsibility and accountability for all students in the classroom. The special educator cannot be viewed as a classroom assistant but must be seen as an equal partner.

Often in the beginning, individual teachers speak of "their" classroom or "their" lesson. Clearly, they have not yet merged as a teaching unit. Use of the word $\underline{\mathrm{I}}$, however, slowly becomes we as the partnerships grow and as parity is achieved. Parity is never completely resolved, though, as partnerships 
continue to grow and change over the years, and teacher roles, as well as related parity issues, must continue to be addressed.

\section{Staff Development}

Staff development is an important component in developing collaborative relationships. Formal training in conflict resolution and collaboration skills is helpful in the initial stages. What often proves to be most valuable for the participants as a whole, however, is the time afforded them to plan together and to reflect as a large group and as a partnership.

\section{Classroom Make-Up}

The classroom make-up in a high school program must be diverse and heterogeneous. Collaborative teaching programs are not intended to replicate the old special education classroom or track. Courses should not be overloaded with students who have disabilities. Generally, a classroom of 30 should have no more than 10 students with disabilities. In addition, the less "tracked" the course is, the better the class will be as a whole. While believing in the concept of heterogeneity in a classroom, teachers acknowledge the difficulties and challenges these classroom arrangements bring. As an English teacher stated:

\begin{abstract}
The downside of it is that when you have that range, you obviously have some upper-end kids who really need to be challenged. You can't rely on them all the time to be the teacher. You have to allow them opportunities to expand their own knowledge and skills. And while they are achieving a lot in terms of self-esteem and true understanding of the concepts through teaching others-it is clarified for them and they are getting the benefits of that- the pace is one that is not really good for them. They can get bored with it, they feel like they are belaboring it when you do a review. So I think it is important to be able to provide opportunities for them to expand, to grow, and we work really hard at that.
\end{abstract}

\section{Time}

Time is a frequently mentioned concern of teachers. Time is important on two levels:

1. Time on a daily basis to talk and plan with the teaching partner;

2. Time built into the school calendar to talk and make connections with others involved in this change initiative.

The time needed should not be added to the end of a busy day but, rather, built into the teachers' work day and year. Possibly, teachers value time more than any other factor be- cause in the day-to-day life of teaching, teachers have little if any control over their time. Their days often are routine in terms of schedule, with little flexibility and limited power to change or adjust for extenuating circumstances. Teachers' time with students is improved as a result of their time with colleagues. Providing time for teachers to share must become a priority if ongoing reflection, renewal, and growth is to take place. Teachers consistently mention time as a key to the development of partnerships and professional growth.

\section{Evolution of Teaching Partnerships}

Participants in collaboration and co-teaching programs acknowledge that their involvement in the program makes them better teachers and better people. This does not happen immediately. Each teacher has to work out differences in teaching styles. Each teacher has to formulate ways to make public the ideas, concepts, and hunches that make up his or her teaching process, which are silent or unexamined when teaching alone. In addition, each special educator moves from a relatively secure environment (the resource classroom or a self-contained classroom) to an unknown environment. Defining new roles and dealing with interpersonal interests are two major issues that partnerships have to face.

Typically, teachers experience an evolutionary change over the course of the first year of a program. At first their concerns as participants are procedural or "how to" in nature: how to grade students, how to pace a lesson, how to deal with certain behaviors. It is as though the participants are seeking a recipe, something to grab onto to ensure that they are doing it right.

Once they acknowledge that there is not a recipe and that "doing it right" means different things for different partnerships, procedural concerns give way to reflections on teaching and learning. With time, the special education teachers define their roles further and begin to feel more confident as teachers. They begin to realize that they are having an impact on a larger number of students than they did in the past and that all students are accepting them as a teacher. This turns out to be a great ego builder. As a teacher of students with disabilities noted:

It is wonderful to walk down the hall and be able to say "hi" to that number of kids and know you have had an impact on them. As a special ed person, I never had that before. There was my own little separate group, and that was it. That for me makes it really great.

\section{Benefits of Partnerships}

Teachers who have been involved in partnerships at Roosevelt High School agree that many benefits accrue from these programs. These benefits can be summarized as follows: 
1. Administrative duties (e.g., attendance taking, grading, copy machine duties, parent phone calls) are shared.

2. Having two teachers in the classroom allows them to give more attention to problem behaviors and crisis situations without disrupting the entire class.

3. More time is available to give students individual attention and get to know them better.

4. Evaluation and feedback from a colleague allows teachers to fine-tune lessons on a daily basis.

5. Daily contact with a colleague provides opportunities for problem solving, bouncing ideas off one another, risk taking, and being creative regarding challenging student behaviors.

6. Renewal and reinforcement come from watching good teaching and working together.

7. Teachers model collaboration and cooperation for students.

8. Each teacher is able to use his or her strengths to address student needs. For example, if one teacher has difficulty addressing a challenging student behavior, the other teacher can step in and provide support.

General education teachers, too, frequently comment on how the skills they gain while teaching with a partner generalize to other classes. One teacher addressed the changes made in a class where he works with a partner by stating:

Now that Gary and I have worked together for two years, I find myself thinking about [these changes] an awful lot in every class, not just in the general math class [where the partnership occurred]. I don't know that I can prove it, but my guess is that calculus instruction is better, in a measurable way, than in the past as a result of the partnership.

\section{An Example of a Partnership at Work}

The greatest benefits from partnerships relate to the transformations in general education classrooms. The following example illustrates the outcome of a partnership between a high school math instructor (also head of the mathematics department) and a teacher of students with disabilities. These teachers developed a partnership to teach a general math class. As with all partnerships at Roosevelt High School, students with disabilities in this class formerly had been taught in a separate, special education classroom. In large part, this example is described in the words of the two teachers who formed the partnership. The quotes are taken from interviews by the first author of this article, conducted as part of her dissertation research (Cole, 1995).

\section{Background-General Math}

As the partnership began, both teachers had strong reservations regarding the extent to which the general math class was meeting the needs of typical students, or the extent to which the class would meet the needs of newly enrolled students with disabilities. The math teacher put this well in stating:

\begin{abstract}
To give you a little background about the general math course we teach, general math has been around since the rocks cooled off, and I don't think that ever during that time it has been completely satisfactory for the vast majority of kids in the class. I felt free to experiment with general math because it has been so unsuccessful for decades, not just at this school, but everywhere.
\end{abstract}

This teacher went on to describe the basic content of the course, as it had been taught for many years.

The prevailing idea of general math was, "Let's make one more effort at teaching arithmetic." The skills that were being practiced were nothing new. It is built around two components: There were these problems where you get fifty whole-number division problems $\ldots$ and verbal problems. It had grown up historically around a lot of drill work.

An experience common to both teachers early in the first year of their partnership served to solidify their perspectives on the types of changes that had to occur in the general math class.

(We) had an experience that also contributed to the mix. The local Chamber of Commerce had started what it called a Partners in Education Program. This was a collaborative effort on the part of educators and business leaders. As a part of that program, the teachers involved spent a week in local industries. I spent a week at Westinghouse, and Gary at RCA. In that shared experience, he and I brought together some notes about what we had seen at those factories, and it was plain as day to us that the kinds of situations our kids are going to be leaving high school and entering are nothing like the general math class was preparing them for.

This realization led Gary and Adam to begin examining the curriculum of the general math class, as well as what students were learning from that curriculum:

I've got kids who knew that September was wholenumber division month, and it was going to be followed by whole-numbers tracking week, and they were going to be followed by whole-number multiplication month, and so forth. It dawned on me that they are not solving problems. You give them a verbal problem and they weren't very successful at story problems. Why? Because they see a problem, they pick out the numbers, they know it is whole-number addition week, so they add the whole numbers together, and zip, they go right on. When we presented 
situations where they had to determine whether those numbers should be added or subtracted, it was a whole new ballgame. I was real impatient to do something about general math in a major way.

\section{Altering Curriculum and Instruction}

Gary and Adam then began exploring alternatives for the general math curriculum. They questioned initially whether they could build the curriculum around a textbook. The following comments illustrate the evolution of their thinking on this matter.

\begin{abstract}
The textbooks are written well, more or less. There is a great variety in those, but there aren't very many that can really help a kid learn.

Textbooks need to cut out the superfluous language and put the info into a clear and concise language that students can use.

We made a decision to take the textbook and throw it away.

We both thought the textbook was too unwieldy for not just the students with special needs but also for the math student period. So our goal was to basically rewrite the textbook in a language that would be concrete, understandable, readable, clear, and still be workable to use the math in their world. We didn't want it to be so simplistic that it was unusable in the real world.
\end{abstract}

The alternative that Gary and Adam decided upon for the general math class was to "run the entire class on the basis of the Math Manual." The format and content for the Math Manual was designed by the teachers, modeled after some of their experiences in observing workplaces.

\begin{abstract}
What we decided was to build the course around the concept of an operator's manual-a manual of procedures for the job, the tasks the job is composed of. The Math Manual ends up looking like a folder. Because what we saw in those workplaces was a collection of people whose jobs are so complex that they can't keep it all in their heads at once- the way we ask kids to memorize multiplication tables, know the area of triangles, and so forth. In fact, what we have provided our students is a set of reference materials.
\end{abstract}

Thus, these teachers moved from having students memorize facts (such as multiplication tables) to helping students solve problems and understand the process used to solve problems. The Math Manual was developed by students.

Students have compiled this folder through several means. They have taken notes off the board, and we have taught note taking by doing that. We have done some pages and handed them out and used them in class. And we have a hybrid of the two-some pages that we hand out and go through them in class and they fill in blanks. There is a table of contents at the beginning that they have kept up-to-date. We check this periodically for a grade.

As Gary and Adam described the purpose of the Math Manual, this manual clearly reflects a significant change in teaching philosophy for both teachers.

This is a big change for most teachers. A major part of the course is devoted to using the manual. The only way to pass tests is to have that manual available, because some of the questions say, "Do not answer the question; just tell us what page you would look at to help you answer the question." That is a reference skill.

They elaborate regarding how the Math Manual is used in their class.

That manual-and this is the key-is used all the time-for tests, quizzes, projects, homework, and so forth. That manual is an integral part of what they do. ... A major portion of the course is devoted to using the manual. Change we did-and essentially we have written our own curriculum.

This change in curricular focus also emphasized lessening student dependence on teachers and helping them discover that they could solve problems independently.

I have held their hands for too long. I've tried to get away from that and point out that it is okay to get stuck. The important thing is to know what you do when you get stuck. How do you behave at that point? Do you throw up your hands in disgust? Or do you go back to the point where you understood things last and go over that territory again, or maybe with someone else?

What we have found was students coming to us with this attitude: "I don't know how to do this, and I'm not going to do it. I don't know how to reduce a fraction, so I'm not going to reduce a fraction. I'll go on to the next question." That is in direct conflict to what we saw in the workplace. That attitude is incompatible with success in the workplace. You don't say, "I don't know how to make the Big Mac; therefore I'm not going to make a Big Mac for this customer." Yet, we found our students internalizing that kind of learning philosophy, so what we have done is add a qualifier to the statement, "I don't know how to do this, so I'm going to go find a place where I can find out how to do this." That seems to parallel the workplace, in an assembly line, a retail place, a restaurant, or just about anything you do outside of school.

One of the teachers synopsized this perspective when he stated:

They don't remember how to add fractions, and frankly I don't care. That's something they could 
find out if they had to. They know it is written down someplace, and if they need that kind of information, they can do it.

In some ways, the general math class borrowed from perspectives of many general educators, as instruction took on a more "constructivist" or process learning model of instruction (Heshusius, 1995). The teachers also adopted methods used widely in special education. The criterion they used for selecting instructional approaches was, "Does it work with our students?" For example, with some of the course content, they emphasized breaking down tasks into incremental steps for instruction:

The incrementals, the tiny step-by-step is the sort of thing we all probably should be doing. Textbooks, standard published materials, probably don't do it. They make huge assumptions about how far a kid can go within the space on one problem. Try someday to sit down and figure out how you know how to read a ruler. I haven't found a textbook yet that describes that.

We've spent a lot of time thinking over the tiny little details that someone needs to go though to learn how to do something that most of us take for granted. Drawing a line with a ruler-we took two days just talking about the technique, how to hold it, how to use it. Then we did some exercises that resulted in some really nice designs.

There was also much more emphasis on hands-on activities in this class rather than lecturing, drill, and practice.

We have gone to a lot of hands-on types of activities. One of the things that bothered me as a parent, for my own kids, was that they could read about measurement, but they never actually did any measuring. In our class, kids measure tire pressure, they measure lumber, and we find out that those things are valuable. We have concentrated on a lot of hands-on things.

\section{Changes in Expectations and Student Evaluation}

Both teachers recognized that in the past they had expected far too little of their students.

We are both pleasantly surprised at the capability of these students. When we raised our expectations of them, we found that we can go higher, faster; we can go into things that we never even ventured into last year. It's like the more we try, the more we find these students are capable of doing.

At least part of this success is attributed to the emphasis on modeling the classroom after the workplace.

There are a number of things we want students to do, and we're asking them to do a better job of what they're doing and holding them to a higher standard by maintaining this workplace analogy as much as we can.

Today kids are making drawings with a ruler. They are actually doing what would pass for mechanical drawing, from a thumbnail sketch of a house. They are measuring; they are looking; they are trying to figure stuff out. We gave them a sloppy sketch of a house with dimensions all over it and they had to come up with a nice drawing that was accurate. And that's an important skill for kids to have when they leave this school, to have at least encountered. And it was not part of the general math curriculum. It's not in a textbook anywhere.

\section{Evaluating Student Progress}

These altered expectations, as well as changes in curriculum and instruction, were reflected in altered methods of evaluating student progress. Putting together the Math Manual constitutes a major part of each student's grade. Further, tests often focus on use of the Math Manual to solve problems or to find information that will aid the student in solving problems. These changes were a new experience for most, if not all, of the students, and it took some time for the students to adjust.

Initially students balked. [One of the first tests] just threw them for a loop. They thought we were kidding. [They said], "What do you mean we don't answer these?" This was an entire math test, and it took about 50 minutes of simply going through their Math Manual and finding the page number where they would get the answers to those questions. That was really foreign to those students because they come in with a mentality of, "Look, all we have to do is get this done." Now they are so used to this that it is real comfortable for them to do these kinds of process exercises. We have some students [looking through] each page. You will see others getting the gist of what the question is and going to the table of contents.

To reflect further the emphasis on the workplace, the teachers also included group activities on some tests.

On some tests a component of the test was group work. The test that you would see isn't a test in the traditional sense. We begin by emphasizing the resources they have available: They have their group that they can call on; they have notes they've made on the geometry unit; they have a textbook they can use as a resource rather than the central focus of the class. They have their calculators that we not only hand to them but teach them how to use. [Calculators] become an object of instruction as well.

The test consisted of several tasks they were to perform together as group-supporting one another, and we go around supporting the group interaction. We are 
kind of coaching them: Can you learn from one another? Here's someone who knows what's happening. Help that person explain to other members in the group.

\section{CONCLUSION}

The experience of Roosevelt High School is one example of how inclusion can work effectively. The indispensable aspect of this program is the collaborative partnerships used to transform classrooms into settings in which the needs of a broad range of students can be met. These partnerships require significantly different roles for teachers of students with disabilities, as well as for content-area teachers. They also require that teachers become equal partners in the education of all students. Periodically integrating teachers of students with disabilities into the general education classroom on an "as needed" basis was not possible or sufficient to achieve these goals.

At Roosevelt, only through the teamwork of the teaching partnerships were classes transformed. Indeed, the curriculum and instruction were "reinvented" to better meet the needs of all students. Through these transformations classes became more learner-centered rather than remaining traditional, content-centered classes, teachers shared their expertise and learned to adapt instruction to the needs of a broad range of students, and assessment and evaluation were altered to better reflect student needs.

Considering the complexity of secondary schools and classrooms, we must recognize that effective inclusive programs cannot be developed short of collaborative partnerships of teachers who bring a range of expertise to these endeavors. There is no "one-size-fits-all" approach for secondary level inclusive programs. Only through sharing the best ideas available in a given secondary setting can effective programs, tailored to the individual needs of a given school, be developed.

\section{REFERENCES}

Affleck, J. Q., Madge, S., Adams, A., \& Lowenbraun, S. (1988). Integrated classroom versus resource model: Academic viability and effectiveness. Exceptional Children, 54, 339-348.

Banerji, M. \& Dailey, R. (1995). A study of the effects of an inclusion model on students with specific learning disabilities. Journal of Learning Disabilities, 28(8), 511-522.

Bear, G. G., \& Proctor, W. A. (1990). Impact of a full-time integrated program on the achievement of nonhandicapped and mildly handicapped children. Journal of Exceptionality. 1, 227-238.

Blackorby, J. \& Wagner, M. (1996). Longitudinal postschool outcomes of youth with disabilities: Findings from the National
Longitudinal Transition Study. Exceptional Children, 62(5), 399-413.

Council for Exceptional Children (CEC) (1995). Creating schools for all our students: What 12 schools have to say. Reston, VA: Author.

Cole, C. (1995). A contextualized understanding of teachers' practice, their collaborative relationships, and the inclusion of students with disabilities. Unpublished doctoral dissertation (AAC9601781), Indiana University, Bloomington.

Cuban, L. (1984). How teachers taught: Constancy and change in American classrooms 1890-1980. New York: Longman.

Deshler, D., Schumaker, J., Lenz, K., \& Ellis, E. (1984). Academic and cognitive interventions for LD adolescents: Part II. Journal of Learning Disabilities, 17(3), 170-179.

Ellis, E. (1993). Integrative strategy instruction: A potential model for teaching content area subjects to adolescents with learning disabilities. Journal of Learning Disabilities, 26, 358-383.

Espin, C., \& Foegen, A. (1996). Validity of general outcome measures for predicting secondary students' performance on content-area tasks. Exceptional Children, 62(6), 497-514.

Fuchs, D., \& Fuchs, L. (1994) Inclusive schools movement and the radicalization of special education reform. Exceptional Children, 60, 294-309.

Guterman, B. (1995). The validity of categorical learning disabilities services: The consumers' view. Exceptional Children, 62(2), 111-124.

Hartgraves, A. (1993). Individualism and individuality: Reinterpreting the teacher culture. In J. Little \& M. McLaughlin (Eds.), Teachers' work. New York: Teachers College Press.

Heshusius, L. (1995). Holism and special education: There is no substitute for real life purposes and processes. In T. Skrtic (Ed.), Disability and democracy: Reconstructing (special) education for postmodernity (pp. 166-189). New York: Teachers College Press.

Kauffman, J., Lloyd, J., Baker, J., \& Riedel, T. (1995). Inclusion of all students with emotional and behavioral disorders? Let's think again. Phi Delta Kappan, 76(7), 542-546.

McLeskey, J., \& Waldron, N. (1995). Inclusive elementary programs: Must they cure students with learning disabilities to be effective? Phi Delta Kappan, 77(5), 300-303.

Mercer, C., \& Mercer, A. (1993). Teaching students with learning problems (4th ed.). New York: Macmillan.

Mikulecky, L., Albers, P., \& Peers, M. (1994). Literacy transfer: A review of the literature (Technical report TR 94-05). Philadelphia: University of Pennsylvania, National Center on Adult Literacy,

Mikulecky, L., \& Lloyd, P. (1993). The impact of workplace literacy programs: A new model for evaluating the impact of workplace literacy programs (Technical report TR 93-2). Philadelphia: University of Pennsylvania, National Center on Adult Literacy.

Oakes, J. (1985). Keeping track: How students structure inequality. New Haven, CT: Yale University Press. 
Polloway, E., Patton, J., Epstein, M., \& Smith, T. (1993). Comprehensive curriculum for students with mild disabilities. In E. Meyen, G. Vergason, \& R. Whelan (Eds.). Educating students with mild disabilities (pp. 255-272). Denver: Love Publishing. Rieth, H., \& Polsgrove, L. (1994). Curriculum and instructional issues in teaching secondary students with learning disabilities. Learning Disabilities Research \& Practice, 9(2), 118-126.

Scanlon, D., Deshler, D., \& Schumaker, J. (1996). Can a strategy be taught and learned in secondary inclusive classrooms? Learning Disabilities Research and Practice, 11(1), 41-57.

Schumaker, J., \& Deshler, D. (1988). Implementing the regular education initiative in secondary schools: A different ballgame. Journal of Learning Disabilities, 21(1), 36-42.

Schumaker, J., Deshler, D., Alley, G., \& Warner, M. (1983). Toward the development of an intervention model for learning disabled adolescents. Exceptional Education Quarterly, 4(3), 295-304.
Smith, T., Polloway, E., Patton, J., \& Dowdy, C. (1995). Teaching children with special needs in inclusive settings. Boston: Allyn \& Bacon.

Will, M. (1986). Educating children with learning problems: A shared responsibility. Exceptional Children, 52, 411-415.

York, J., \& Reynolds, M. (1996). Special education and inclusion. In John Sikula (Ed.), Handbook on research on teacher education (2d ed.) (pp. 820-836). New York: Macmillan.

Zigmond, N. (1990). Rethinking secondary school programs for students with learning disabilities. Focus on Exceptional Children, 23(1), 1-22.

Zigmond, N, Jenkins, J., Fuchs, L., Deno, S., Fuchs, D., Baker, J., Jenkins, L, \& Couthino, M. (1995). Special education in restructured schools: Findings from three multi-year studies. Phi Delta Kappan, 76(7), 531-540.

\title{
NEW FOR 1997
}

\section{Techniques for Managing a Safe School}

\author{
Beverley H. Johns, Four Rivers Special Education District, Jacksonville, Illinois \\ John P. Keenan, Assistant Chief of Police, Jacksonville, Illinois
}

This book provides practical step-by-step methods for creating and managing a safe school. It specifically focuses on techniques for combating truancy, collaborating with police, initiating gang prevention and intervention measures, methods for conflict resolution, dealing with sexual harassment, and managing a variety of crises. The text gives solutions to these problems that are based on the actual experiences of the authors.

The text is designed for all educators who inevitably will face students with behavioral problems. The book provides these educators with solutions that work for managing a safe school.

\section{Special Features}

- Practical step-by-step techniques for creating and managing a safe school

- Includes many sample policies and procedures for assuring safe schools

- Covers the appropriate use of searches and interventions

- Separate chapter discussing collaboration with police and the judicial system

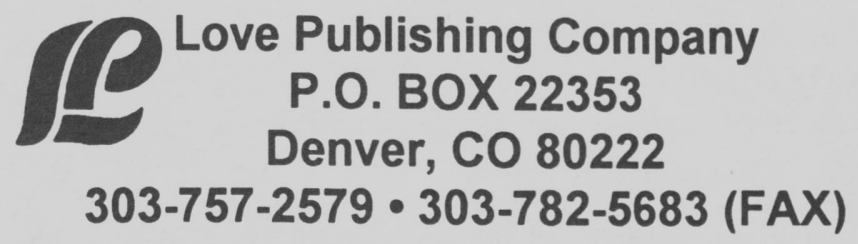




\section{Professional update}

\section{National Association of School Psychologists}

April 1-5, 1997

Anaheim Hilton Hotel

Anaheim, California

Contact: National Association of School Psychologists 4340 East West Highway

Suite 402

Bethesda, MD 20814

\section{International Association of Special Education}

August 3-7, 1997

Cape Town, South Africa

Contact: Helmi Owens

School of Education

Pacific Lutheran University

Tacoma, WA 98447

(206) $535-7292$

\section{Council for Exceptional Children}

April 9-13, 1997

Annual Conference

Salt Lake City, Utah

Contact: Council for Exceptional Children 1920 Association Drive

Reston, VA 22091

\section{The China - U.S. Conference on Education}

July 9-13, 1997

Beijing, People's Republic of China

This will be the largest gathering of Chinese and American educators ever assembled. Conference cost is $\$ 2,850$ for a nineday Conference Program Package including international airfare, meals, lodging, conference fees, cultural and historic sites in Beijing. Also available are study programs to other cities, a demonstration learning center, and school partnerships. For detailed information on the Conference contact:

Global Interactions, Inc.

Department GC-97

14 West Cheryl Drive

Phoenix, AZ 85021

Telephone: 602-943-3922

Fax: 602-943-4458

\section{PERMISSIONS AND COPYRIGHT}

All rights are reserved. No part of this publication may be reproduced, photocopied, faxed, stored in a retrieval system, or transmitted, in any form or by any means, electronic, mechanical, recording or otherwise, without the prior written permission of the publisher.
Back issues are available for sale. Reproduction requires permission and payment of fees. It is illegal and a violation of federal copyright law to reproduce this publication without permission. Direct all inquiries to the permissions editor. 